\title{
Comparison of equipment for grain sampling
}

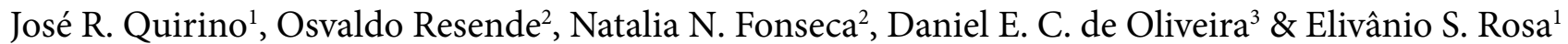 \\ ${ }^{1}$ Caramuru Alimentos S.A. Rio Verde, GO, Brasil. E-mail: zeronaldo@caramuru.com - ORCID: 0000-0003-4668-5546; elivanio@caramuru.com - ORCID: \\ 0000-0002-9219-9592 \\ ${ }^{2}$ Instituto Federal de Educação, Ciência e Tecnologia Goiano/Diretoria de Pesquisa e Pós-Graduação. Rio Verde, GO, Brasil. E-mail: osvresende@yahoo.com.br \\ (Corresponding author) - ORCID: 0000-0001-5089-7846; natnogueira1996@hotmail.com - ORCID: 0000-0002-3879-7743 \\ ${ }^{3}$ Instituto Federal de Educação, Ciência e Tecnologia Goiano. Iporá, GO, Brasil. E-mail: oliveira.d.e.c@gmail.com - ORCID: 0000-0002-3824-994X
}

\begin{abstract}
Grain sampling requires the use of appropriate and accurate equipment. This study aimed to compare grain samplers, manual and mechanical, used in the sampling of soybean loads, during their reception by storage units. The used devices were the manual sampler with $1.80 \mathrm{~m}$ length and three opening stages, $2.10 \mathrm{~m}$ length and three opening stages; and $2.10 \mathrm{~m}$ length and one opening stage, besides the mechanical sampler (pneumatic) and the pelican sampler. The analyzed parameters were the contents of impurity, broken grains, pods, immature grains, and moisture. The significance of effect of treatment was determined by $\mathrm{F}$ Test and the means were compared by Tukey test $(\mathrm{p}<0.05)$. The devices used for sampling of soybean grains in vehicles, during their reception by storage units, affect the determination of broken grains, pods and immature grains. However, there was no difference between the types of sampling equipment in the determination of impurity content, and the pelican sampler collected greater percentages of pods and immature grains from the sampled vehicles.
\end{abstract}

Key words: classification, grain samplers, impurities, pods

\section{Comparação de equipamentos para amostragens de grãos}

RESUMO: A amostragem de grãos requer a utilização de equipamentos adequados e precisos. Assim, objetivou-se comparar caladores (amostradores) de grãos, manual e mecânico, utilizados na amostragem de cargas de soja durante o recebimento em unidades armazenadoras. Os equipamentos utilizados foram os caladores manuais de 1,80 m e três estágios de abertura, 2,10 m e três estágios de abertura, 2,10 m e um estágio de abertura, amostrador mecânico (pneumático) e o calador tipo pelicano. Os parâmetros analisados foram as percentagens de impurezas, de grãos quebrados, percentagens de vagens, grãos imaturos e teor de água. A significância do efeito dos tratamentos foi determinada pelo Teste $\mathrm{F}$, e as médias comparadas pelo teste Tukey $(\mathrm{p}<0,05)$. Os equipamentos utilizados para amostragem de grãos de soja em veículos, durante o recebimento em unidades armazenadoras, influenciam na determinação do teor de grãos quebrados, vagens e grãos imaturos. Entretanto, não houve diferença para o tipo de equipamento estudado na determinação do teor de impureza, tendo o amostrador tipo pelicano coletado maiores percentuais de vagens e grãos imaturos nos veículos amostrados.

Palavras-chave: classificação, caladores, impurezas, vagens 


\section{INTRODUCTION}

Brazil is the second largest soybean producer, only behind the United States (Marcandalli et al., 2011; Almeida et al., 2016), and largest exporter of this oilseed crop. However, according to Freitas (2011), qualitative and quantitative losses during soybean postharvest processes are frequent.

Sampling is usually the major source of error in an analysis and the inaccuracy in this process may result in misinterpretation of the actual characterization of the lot. The sample should be obtained in such a way that all grains composing the lot have the same chance of being sampled (Whitaker, 2003).

The devices commonly used to collect samples in vehicles, to determine the defects in grains, are the double-tube samplers (manually-operated), mechanical samples (pneumatic) and pelican samplers.

In double-tube samplers, which may vary in number of compartments, number of opening stages and in size, the sample penetrates each compartment by gravity.

Regarding the grains, higher moisture content leads to increased roughness on the surface, causing higher resistance to the sliding of one particle against another, increasing the angle of repose and the coefficients of static and dynamic friction, which compromises the sliding, as observed in green wheat (Al-Mahasneh et al., 2007), peanut (Aydin, 2007) and sunflower (Gamea, 2013).

In Brazil, double-tube samplers are obligatory in all bulk storage units (Brasil, 2011). Mechanical samplers (pneumatic) are used to collect samples in vehicles which have exposed surface, whereas the pelican sampler is indicated for the sampling of freefalling grains and is frequently used during the discharge of the materials.

Thus, this study aimed to compare the different types of samplers, manual and mechanical, used in the sampling of soybean loads during the reception in storage units.

\section{Material ANd Methods}

The experiment was conducted during the 2014/15 season at the soybean grain storage units of the company Caramuru
Alimentos S/A, located in the cities of Portelândia - GO $\left(17^{\circ}\right.$ $23^{\prime} 56.83^{\prime \prime} \mathrm{S}$ and $\left.52^{\circ} 40^{\prime} 41.73^{\prime \prime} \mathrm{W}\right)$ and Morrinhos - GO (17 $43^{\prime} 40.08^{\prime \prime} \mathrm{S}$ and $49^{\circ} 3^{\prime} 51.67^{\prime \prime} \mathrm{W}$ ).

The experimental design was randomized blocks with five treatments (grain samplers) and 14 blocks (trucks sampled at the storage units), in three repetitions. Treatments consisted of the following devices: a) manually-operated double-tube sampler, with $1.80 \mathrm{~m}$ length and 12 sampled intakes, divided into three stages $(1.80-3 \mathrm{~S})$; b) manually-operated double-tube sampler with $2.10 \mathrm{~m}$ length, 14 sample intakes and three stages $(2.10-3 S)$; c) manually-operated double-tube sampler with $2.10 \mathrm{~m}$ length, 14 sample intakes and one stage $(2.10-1 \mathrm{~S})$; $)$ mechanical sampler with 37-mm-diameter tip; and e) pelican sampler, as detailed in Table 1 .

The mechanical sampler (pneumatic) is composed of an airflow sampling system, in which the rod penetrates bulk grains by the activation of the hydraulic controller, which selects the site and specifies the number of points sampled. The collecting rod has two tubes, one with internal diameter of $0.0442 \mathrm{~m}$ and another with external diameter of $0.0662 \mathrm{~m}$ and length of $1.90 \mathrm{~m}$. A fan creates a downward airflow between the external and internal tubes that, when crossing the bulk grains collected by the tip ( $0.037 \mathrm{~m}$ diameter), displaces the grains upward through the internal tube, which has another airflow that sucks the bulk grains into the collecting tube, conducting the sample to the reservoir (Figures $1 \mathrm{~A}$ and $\mathrm{B}$ ).

The pelican sampler (Figure 1C) has the following dimensions: $0.099 \mathrm{~m}$ width, $0.10 \mathrm{~m}$ length, $0.077 \mathrm{~m}$ of smaller height and $0.16 \mathrm{~m}$ of greater height, with a total collection area of $0.01 \mathrm{~m}^{2}$, collecting an estimated mass of $0.879 \mathrm{~kg}$. Samples were collected in triplicate for each point of discharge

Table 1. Characterization of the samplers used with respect to measurements of useful diameter, number of sample intakes, construction material and estimated volume per sampling

\begin{tabular}{lccc}
\multicolumn{1}{c}{ Device } & $\begin{array}{c}\text { Cylinder } \\
\text { diameter }(\mathbf{m})\end{array}$ & $\begin{array}{c}\text { Construction } \\
\text { material }\end{array}$ & $\begin{array}{c}\text { Estimated volume } \\
\text { per sampling }\left(\mathbf{m}^{\mathbf{3}} \mathbf{\times} \mathbf{1 0}^{\mathbf{3}}\right)\end{array}$ \\
Sampler 2.10 m-3S & 0.0287 & Aluminum & 1.163 \\
Sampler 1.80 m-3S & 0.0312 & Brass & 1.181 \\
Mechanical sampler & 0.0442 & SAE 1020 steel & -- \\
Pelican sampler & -- & Steel plate & 1.173 \\
Sampler 2.10 m-1S & 0.0312 & Brass & 1.380 \\
\hline
\end{tabular}

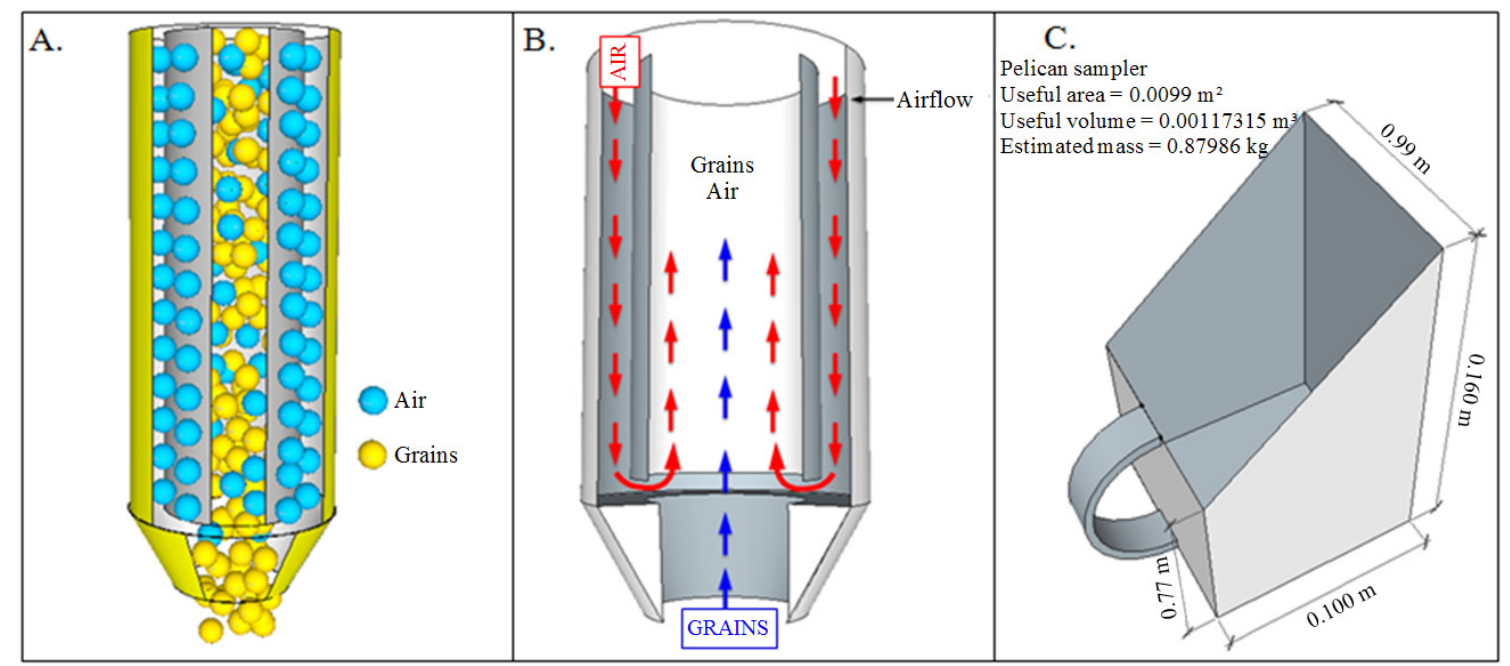

Figure 1. Schematic of the airflow and grains in the mechanical sampler during the sampling operation (A, B); pelican sampler used in the experiment with dimensions and capacity (C) 
(discharge spout) during the free fall of the product at the discharge spouts and also during the first discharge with the squeegee, manually performed by the discharge worker. Samplings were performed through the discharge spouts installed in the bodies of the trucks.

The samples collected with double-tube and mechanical samplers were collected at predetermined points in the vehicle, in a zig-zag pattern (Figure 2), previously marked with polyvinyl chloride (PVC) tubes with diameter of $0.10 \mathrm{~m}$.

Homogenization and division of samples were performed in a Boerner divider, in which the samples were firstly passed three times and then divided, for each repetition, in triplicate, with minimum mass of $0.125 \mathrm{~kg}$ (Brasil, 2007).

The subsamples of each repetition were placed in rectangular sieves $(0.4 \times 0.3 \mathrm{~m})$, with circular $0.003-\mathrm{m}$-diameter apertures, and manually moved for $30 \mathrm{~s}$ (Brasil, 2007), to separate pods, immature grains, foreign material and impurities. Then, the samples free from impurities were placed on sieves with oblong apertures $(0.004 \times 0.012 \mathrm{~m})$ to identify broken grains The measured masses of each repetition were transformed to percentage in relation to the initial mass of each subsample. The samples used to determine the moisture content were collected separately, per device, in each vehicle sampled according to ASAE (2003).

The significance of effect of treatment was determined by $\mathrm{F}$ test, and means were compared by Tukey test $(\mathrm{p}<0.05)$, using the program Sisvar 5.6 (Ferreira, 2014).

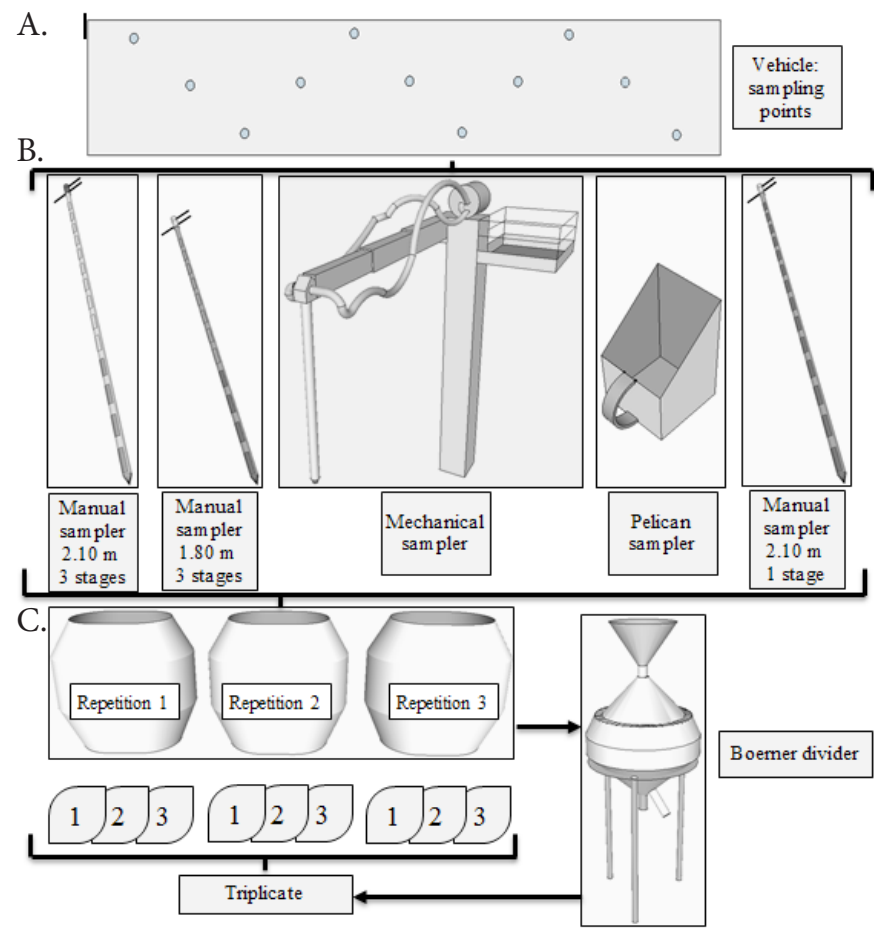

Figure 2. Schematic representation of the procedures for soybean grain sampling: (A) sampling points in the vehicle to collect the samples; (B) devices used for sampling; (C) homogenization and division of samples

\section{Results AND Discussion}

The content of impurity and foreign material did not differ among the studied samplers, showing overall mean of $1.14 \%$. The content of impurities influences the calculations of the processes of drying, cleaning, aeration, classification and storage of grains (Figueiredo Neto et al., 2012; Gratão et al., 2013), because they occupy intergranular spaces and reduce bulk grain porosity.

The sampling devices had effect on the percentages of broken grains, pods, immature grains and on the moisture content of soybean grains sampled in the vehicles during their reception at the storage units (Figure 3 ).

The pelican sampler showed the lowest content of broken grains, followed by the mechanical sampler, which did not

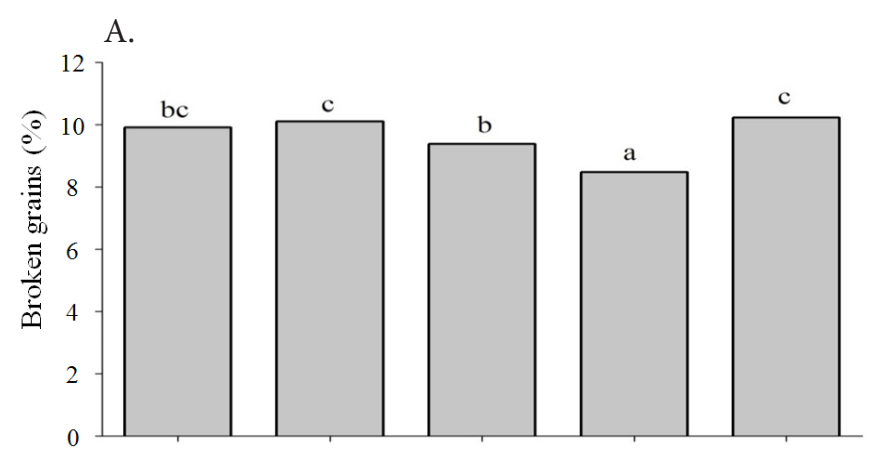

B.

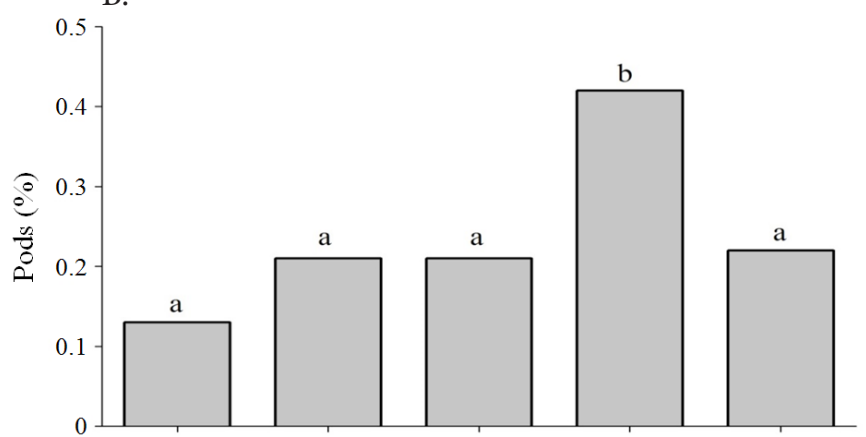

C.

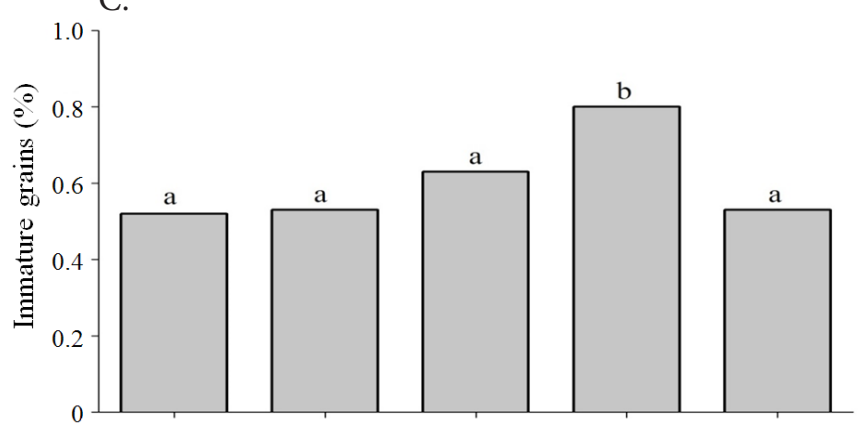

D.

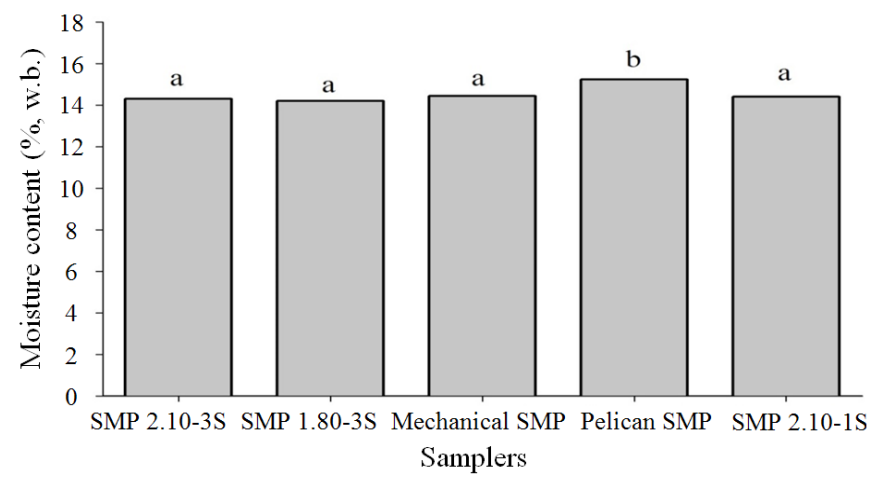

Means followed by the same letter do not differ by Tukey test at 0.05 probability level

Figure 3. Broken grains $(A)$, pods $(B)$, immature grains $(C)$, and moisture content (D) in soybean grains collected by the sampling devices in vehicles during the reception of soybean loads at storage units 
differ from the manual double-tube sampler 2.10 - $3 \mathrm{~S}$ (Figure $3 \mathrm{~A})$. The manual double-tube samplers did not differ from one another in the sampling of broken grains. The highest means of broken grains collected by double-tube samplers may have occurred due to the breaking of grains positioned between the internal and external cylinders, which cause rupture when they are twisted to close, especially in products with higher moisture content, because the higher the moisture content, the lower the force required to cause rupture and breakage of grains (Aydin, 2007).

The percentage of broken grains present in the sampled vehicles, regardless of the sampling method, was lower than the maximum limit of tolerance for this defect in the sample, which is $30 \%$ (Brasil, 2007). Above this value, discounts are already established by the reception units.

For the pelican sampler, there was a higher content of pods collected in the samples and it differed from the other samplers in the collection of this impurity (Figure 3B). The pelican sampler showed mean of $0.42 \%$. Considering the overall mean of pods collected $(0.24 \%)$, the pelican sampler collected more than three times the value obtained by the sampler $2.10-3 \mathrm{~S}$ $(0.13 \%)$ and two times the other sampling devices $(0.21 \%)$ used in the study.

The mechanical sampler collected low percentages of pods (Figure 3B), compared to the pelican sampler. The working principle of this device is the terminal speed of the materials and, therefore, the airflow used may have been insufficient to transport the defects due to the higher moisture content and larger physical dimensions.

The sampler $2.10 \mathrm{~m}-3 \mathrm{~S}$ collected lower content of pods. It can be inferred that, since it is built with aluminum, it needs smaller diameter in the internal tube to ensure adequate resistance in the operation, resulting in smaller volume of sampling (Table 1). In addition to that, it was observed during the experiment that the sampler had smaller volume of collected material and constant accumulation of particles, requiring frequent stops in the operations for unclogging, which consequently reduced sampling performance.

The analyses should consider the capacity of the samplers in the collection of pods because at the storage units there has been an increased presence of pods in loads received from plantations. This has occurred over the years in all main soybean producing regions of Brazil and also in the Midsouth of the United States, where it is common to observe plants with green leaves, green stems and/or green pods in plantations of mature soybeans (Griffin et al., 2010).

It should also be emphasized that the causes associated with the presence of green pods in soybean grains are diverse (Silva et al., 2013; Harbach et al., 2016), for instance, the type of plant growth (Boudreaux \& Griffin, 2011). Moreover, green pods during harvest can be threshed by the threshing mechanisms of the harvester, culminating in the release of immature grains in the harvested mass (Sinnecker, 2005).

Based on the results, comparing all devices, the pelican sampler was the one which collected larger amount of immature grains and green pods present in the analyzed samples (0.8\%) (Figure 3C).
Immature grains are those with oblong shape and green color due to an incomplete physiological development. These grains have high chlorophyll content in the cotyledons (Zorato et al., 2007), which compromises the quality and volume of oil (Rangel et al., 2011).

The high moisture content in immature grains favors the development of fungi due to the increased respiratory activity and compromises the storability. Thus, knowing the percentage of immature grains in bulk grains by sampling is fundamental to define adequate strategies of storage (Mandarino, 2012).

Pods and immature grains have higher moisture content than the normal grains present in the loads and, consequently, they may expose larger projected area according to several researchers (Aydin, 2007; Siqueira et al., 2013). Therefore, immature grains and pods have larger area of contact with the mass of grains and undergo lower pressure, which causes sliding over the discharged mass, tending to show greater accumulation on the sides of the loads in the vehicles and in warehouses. This may lead to higher percentages of pods and immature grains collected by the pelican sampler in the discharge of the grains into the hoppers (Figures 3B and C).

In relation to the manual samplers used in the samplings, the length, number of stages and intakes did not cause differences in the collection of impurities, broken grains, immature grains and pods. During the reception of grains at storage units, sampling with manual samplers has limitations because, when there is intense traffic of vehicles loaded with grains for discharge, even if the workers take turns in the operation, fatigue, reduction of performance and loss of sampling quality are common at the end of the working day.

In the present study, there was no difference in the collection of impurities, immature grains and pods between the mechanical sampler and the other double-tube samplers. Thus, the mechanical sampler is an acceptable option to collect samples, especially for larger collecting, intermediate and terminal storage units.

Another important factor is the maintenance of mechanical samplers, which, if performed by untrained people, may alter the dimensions and capacity of the devices, which may lose efficiency in the collection of some types of defects, causing losses to the parts involved. Periodical maintenance to check for wear, cleaning of duct and hose systems, change of hydraulic oil are also fundamental for good performance of this device.

The moisture contents of soybean grains were higher than $14 \%$ (w.b.) for all sampling devices (Figure 3D). It should be highlighted that samples collected with the pelican sampler had higher moisture content in the grains, differing from the other devices tested. This fact may be attributed to the presence of immature grains, which naturally have higher moisture content than physiologically mature grains.

Samples obtained with the mechanical sampler, despite being subjected to the airflow used to transport the grains, did not show differences in the moisture content compared to the double-tube samplers. This fact may be attributed to the low moisture content of the grains and to the reduced distance between the collection point and the reservoir of the mechanical sampler (1.92 and $4.0 \mathrm{~m}$ ) at the storage units of Portelândia and Morrinhos, respectively (Figure 3D). 
Carvalho \& Novembre (2012) report that the adequate moisture content for mechanical harvest of soybean seeds is 12 to $15.9 \%$ (w.b.) and, according to Pinto et al. (2012), the moisture content required to ensure less mechanical damage is between 13 and 15\% (w.b.). Smaniotto et al. (2014) recommend moisture content of $12 \%$ (w.b.) for safe storage of soybean grains in hot regions. All loads of grains analyzed had satisfactory moisture content for mechanical harvest (Figure 3D). This can be concluded based on the values of impurities and broken grains in the samples (Figure 3A). It is worth emphasizing that $14 \%$ (w.b.) is not a satisfactory moisture content for storage, particularly in hot regions such as the Midwest, North and Northeast regions of Brazil.

Thus, it is important that the storage unit uses a sampling method that provides safe collection and classification of the product. Assessing the efficiency of sampling equipment is of fundamental importance because they must provide precise information of the lots, regarding moisture content, content of impurities, types of impurities, broken grains and foreign materials. These data may alter the planning of utilization of sieves and grain inlet flows in the machines and in the postharvest operations of the storage unit.

\section{Conclusions}

1. There is no difference among the sampling devices in the determination of the content of impurities and foreign materials.

2. The types of equipment used in the sampling of bulk soybean grains, during the reception at storage units, influence the determination of broken grains, pods and immature grains.

3. Both mechanical and manual double-tube samplers favor the collection of samples containing higher percentages of broken grains in the sampled loads.

4. The pelican sampler is the one which collects largest quantity of pods and immature grains.

\section{ACKNOWLedgments}

To IF Goiano, CAPES, FAPEG, FINEP, CNPq and Caramuru S.A. for the indispensable financial support to conduct the study.

\section{Literature Cited}

Al-Mahasneh, A. M.; Rababah, T. M. Effect of moisture content on some physical properties of green wheat. Journal of Food Engineering, v.79, p.1467-1473, 2007. https://doi.org/10.1016/j. jfoodeng.2006.04.045

Almeida, M. S.; Amaral, M. do; Morabito, R. Um estudo sobre localização de terminais intermodais na rede de escoamento da soja brasileira. Production, v.26, p.562-580, 2016. https://doi. org/10.1590/0103-6513.144513

ASAE - American Society of Agricultural Engineers. ASAE Standards. St. Joseph: ASAE, 2003. 593p.

Aydin, C. Some engineering properties of peanut and kernel. Journal of Food Engineering, v.79, p.810-816, 2007. https://doi. org/10.1016/j.jfoodeng.2006.02.045
Brasil. Instrução Normativa nº 11, de 15 de maio de 2007. Estabelece o regulamento técnico da soja. Brasília: Ministério da Agricultura, Pecuária e Abastecimento, 2007. p.13-15. Seção 1

Brasil. Instrução Normativa no 29, de 8 de junho de 2011. Aprova os requisitos técnicos obrigatórios e recomendados para certificação de unidades armazenadoras. Brasília: Ministério da Agricultura, Pecuária e Abastecimento, 2011. p.12-32. Seção 1

Boudreaux, J. M.; Griffin, J. L. Application timing of harvest aid herbicides affects soybean harvest and yield. Weed Technology, v.25, p.38-43, 2011. https://doi.org/10.1614/WT-D-10-00045.1

Carvalho, T. C. de; Novembre, A. D. da L. C. Qualidade de sementes de soja colhidas de forma manual e mecânica com diferentes teores de água. Semina: Ciências Agrárias, v.33, p.155-166, 2012. https://doi.org/10.5433/1679-0359.2012v33n1p155

Ferreira, D. F. Sisvar: A guide for its bootstrap procedures in multiple comparisons. Ciência e Agrotecnologia, v.38, p.109-112, 2014. https://doi.org/10.1590/S1413-70542014000200001

Figueiredo Neto, A.; Dantas, B. F.; Silva, J. C.; Silva, M. F. Resistência ao fluxo de ar das vagens de amendoim com diferentes percentuais de impurezas. Nucleus, v.9, p.85-91, 2012. https:// doi.org/10.3738/1982.2278.673

Freitas, M. de C. M. de. A cultura da soja no Brasil: O crescimento da produção brasileira e o surgimento de uma nova fronteira agrícola. Enciclopédia Biosfera, v.7, p.1-12, 2011.

Gamea, G. R. Physical properties of sunflower seeds components related to kernel pneumatic separation. International Journal of Engineering \& Technology, v.13, p.103-114, 2013.

Gratão, P. T. da S.; Devilla, I. A.; Servulo, A. C. O.; Jesus, F. F. de; Ferreira, D. de A. Perda de pressão estática em uma coluna de grãos de quinoa. Revista Brasileira de Engenharia Agrícola e Ambiental, v.17, p.848-854, 2013. https://doi.org/10.1590/S141543662013000800008

Griffin, J. L.; Boudreaux, J. M.; Miller, D. K. Herbicides as harvest aids. Weed Science, v.58, p.355-358, 2010. https://doi.org/10.1614/ WS-09-108.1

Harbach, C. J.; Allen, T. W.; Bowen, C. R.; Davis, J. A.; Hill, C. B.; Leitman, M.; Leonard, B. R.; Mueller, D. S.; Padgett, B. R.; Phillips, X. A.; Schneider, R. W.; Sikora, E. J.; Hartman, G. L. Delayed senescence in soybean: Terminology, research update and survey results from grower. Plant Health Progress, v.17, p.76-83, 2016. https://doi.org/10.1094/PHP-RV-16-0008

Mandarino, J. M. G. Grãos verdes: Influência na qualidade dos produtos à base de soja - série sementes. Londrina: Embrapa Soja, 2012. 5p. Circular Técnica, 90

Marcandalli, L. H.; Lazarinni, E.; Malaspina, I. C. Épocas de aplicação de dessecantes na cultura da soja: Qualidade fisiológica de sementes. Revista Brasileira de Sementes, v.33, p.241-250, 2011. https://doi.org/10.1590/S0101-31222011000200006

Pinto, T. L. F.; Mondo, V. H. V.; Gomes Júnior, F. G.; Cicero, S. M. Análise de imagem na avaliação de danos mecânicos em sementes de soja. Pesquisa Agropecuária Tropical, v.42, p.310-316, 2012. https://doi.org/10.1590/S1983-40632012000300010

Rangel, M. A. S.; Minuzzi, A.; Pierezan, L.; Teodósio, T. K. C.; Ono, F. B.; Cardoso, P. C. Presença e qualidade de sementes esverdeada de soja na região sul do estado do Mato Grosso do Sul. Acta Scientiarum. Agronomy, v.33, p.127-132, 2011. https://doi. org/10.4025/actasciagron.v33i1.4852 
Silva, A. J. da; Cantareli, M. G.; Silva, A. L. da. Haste verde e retenção foliar na cultura da soja. Summa Phytopathologica, v.38, p.151156, 2013. https://doi.org/10.1590/S0100-54052013000300001

Sinnecker, P.; Braga, N.; Macchione, L. A.; Lanfer-Marquez, U. M. Mechanism of soybean (Glycine max L. Merril) degreening related to maturity stage and postharvest drying temperature. Postharvest Biology and Technology, v.38, p.269-279, 2005. https://doi. org/10.1016/j.postharvbio.2005.07.002

Siqueira, V. C.; Resende, O.; Chaves, T. H. Shape and size of jatropha beans (Jatropha curcas L.) during drying at different temperatures. Revista Ceres, v.60, p.820-825, 2013. https://doi.org/10.1590/ S0034-737X2013000600010
Smaniotto, T. A. de S.; Resende, O.; Marçal, K. A. F.; Oliveira, D. E. C. de; Simom, G. A. Qualidade fisiológica das sementes de soja armazenadas em diferentes condições. Revista Brasileira de Engenharia Agrícola e Ambiental, v.18, p.446-453, 2014. https:// doi.org/10.1590/S1415-43662014000400013

Whitaker, T. B. Standardisation of micotoxin sampling procedures: An urgent necessity. Food Control, v.14, p.233-237, 2003. https:// doi.org/10.1016/S0956-7135(03)00012-4

Zorato, M. de F.; Peske, S. T.; Takeda, C.; França Neto, J. de B. Presença de sementes esverdeadas em soja e seus efeitos sobre seu potencial fisiológico. Revista Brasileira de Sementes, v.29, p.11-19, 2007. https://doi.org/10.1590/S0101-31222007000100002 